\title{
Effects of School Environment on Student's Spatial Intelligence in Senior High School of Bandung
}

\author{
Faiz Urfan \\ Magister Program of Geography Education \\ Universitas Pendidikan Indonesia \\ Coresponding email: faiz_urfan@student.upi.edu \\ Darsiharjo \\ Department of Geography Education \\ Universitas Pendidikan Indonesia \\ Dede Sugandi \\ Department of Geography Education \\ Universitas Pendidikan Indonesia
}

\begin{abstract}
In geography learning, spatial intelligence is an important component for geography as a discipline that studies about the space. School environment has an important role in geography learning because school environments affect student's spatial intelligence. However, there is not a specific explanation of how the environment can affect to spatial intelligence. The aim of this study is to explain the process of regression between school environment and spatial intelligence. This study is a survey research to do in senior high school in Bandung, with total sample 264 respondents spread across nine schools. The relationship between the school environment and the spatial intelligence can be explained by path analysis with two others variable that is affordance (perception of the environment) and geo-literacy (literacy of geography). Path analysis conducted by researchers using the software SPSS 23 and AMOS 21. This analysis resulted in three models of the equation, those are (1) school environment don't significantly effect to affordance; (2) school environment significantly effect to geo-literacy; (3) geo-literacy significantly effect to the spatial. For more useful and further research, researcher suggests developing spatial intelligence instrument more intensive in order to give valid and standard instrument.
\end{abstract}

Keywords-School environment, affordance, geo-literacy, spatial intelligence.

\section{INTRODUCTION}

Education, in its broadest sense, may be defined as a process designed to inculcate the knowledge, skills and attitudes necessary to enable individuals to cope effectively with their environment (A.Klonari \& A.Likouri, 2015). The school environment influences the success rate of student learning (E.Purwanto, 2001). It was supposed to be taken seriously by school management. But the facts show that it is very rarely the manager or person in charge of the school is designing a school environment with a solid foundation to achieve a goal. Often the school environment considers as a sideline factor adequately catered for in terms of cleanliness and completeness. Though each element in the school environment needs to be synergistic with a strong presence in the classroom learning objectives. This is necessary so that the business arrangement becomes effective school environment so as to produce the optimal school environment to support students' academic quality improvement. The school's environment conducive situation will create peace and comfort in learning that will run both easy to master the subject matter to the fullest (Hespanha, et al, 2009).

One of the aspects that are influenced by the environment of the school to a learner is spatial intelligence. The perception and the human reaction to the events and symptoms in the geographic around it will be recorded in his mind into a structured knowledge-systematic (I.Oktaviana, 2015). Any mobile organism must be able to navigate in its world to survive and must represent the spatial environment in order to do so (I.Sudikno \& Y.Aminah, 2014). The statement confirmed that spatial intelligence has in relation with the environment. Without spatial intelligence, human beings will not be able to adapt to not being able to position itself on the earth's surface and do not know where to move to where to meet their needs. We need a comprehensive review of the literature concerning the differences and distinctions between spatial ability, spatial reasoning, spatial cognition, spatial concepts, spatial intelligence, and environmental cognition (J.Lee \& R.Bednarz, 2012)

In the case of learners, the school environment does not directly affect the spatial intelligence. There are other factors that exist in human beings is more closely related to the environment. Therefore, need to be involved other relevant factors. We propose that undergraduate educators should focus some effort on helping students achieve higher levels of spatial literacy by designing tools that encourage students to engage in advanced problem-solving in a wide range of social science domains (K.Quinnel, 2015). In turn, people will be presented with opportunities to and faced with the need to think spatially in everyday life (K.wilson, 2011). 
The factor expected to explain the influenced of the school environment on spatial intelligence is affordance and geoliteracy. Affordance is the human perception of the environment as a medium where he is on the move. The theory of affordances, which was influenced by Gestalt theory, theorizes that the animal interprets its environment as possibilities of action that are reliant on the physical attributes of the animal and the object (National Geographic Society, 2009) (Quinnel, 2015, hlm. 56). While geo-literacy is a concept that describes the literacy of a person to see the various events and symptoms in the earth's surface with the approach of Geography. Geo-literacy is the ability to reason about Earth systems and interconnections to make far-reaching decisions. Whether we are making decisions about where to live or what precautions to take for natural hazards, we all make decisions that require geo-literacy throughout our lives. This video illustrates what geo-literacy means to individuals and to our global community (N.Newcombe, 1998). This description explains that the school environment has an influence on affordance, then affordance influence the geo-literacy. While affordance and geo-literacy will affect spatial intelligence. This article aims to explain how the school environment affects the spatial intelligence based on that model. After knowing the mechanism, it is expected that the reader can design a school environment effectively to increase spatial intelligence.

\section{METHOD}

The survey research was conducted at the state senior high school in Bandung and Bandung regency with a total sample of 264 respondents. There are three types research instrument used, (1) the observation instrument (school environment), (2) a non-test instrument (affordance), (3) the test instrument (geoliteracy and spatial intelligence). Each measurement data were analyzed with path analysis to knows the influence of each independent variable on the dependent variable in accordances with a model that has been determined.

\section{FINDING AND DISCUSSION}

The data from range measurements processed using IBM SPSS AMOS 21 software. The results of path analysis by the software is displayed in the form of a model that has been included the test results. The test results are presented in the form of standardized equations. For more details can be seen in Figure 1.

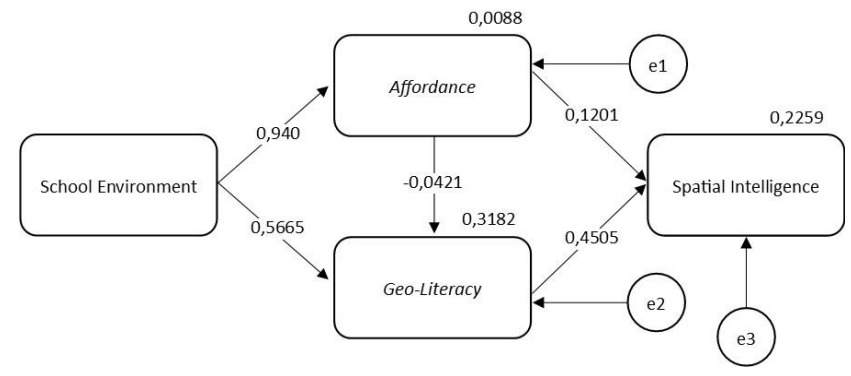

Fig. 1. Full path of diagram research model (Standardized)

Source: Researcher Analysis, 2016

Figure 1 is a standardized model of path analysis results of research variables. Standardized regression equation used to know the contribution each independent variable on the dependent variable. In Figure 1 can be seen, there are five numbers for each regression weight (arrow), which is 0.0940 (W1), 0.5665 (W2), -0.0421 (W3), 0.1201 (W4) and 0.4585 (W5). Then there is also the numbers listed in the variable (the rectangle), namely the affordance (0.0088), geo-literacy $(0.3182)$, and spatial intelligence (0.2259). The numbers contained in the variable is a value squared multiple correlations or multiple coefficients of determination (R2). The $\mathrm{R} 2$ shows the accuracy of the resulting equation. R2 values ranging from $0-1$. The higher the value of $\mathrm{R} 2$, the more accurate the resulting equation. The data indicate a good match with the data model of the analyzed samples is Comparative Fit Index or CFI. CFI value ranging between $0-1$, but recommended greater than 0.9 . If a model to get the value of CFI> 0.9 its can be said that the model is good or matched with the samples tested. This research model has a value of CFI $=$ 0.879 , so this model is a model that can be received and matched with the samples tested.

From the standardized models that have been described, it can be relegated to three regression equation for each variable. There are four variables involved in this research, the school environment (X), affordance (Y1), geo-literacy (Y2), and spatial intelligence (Y3). Here are three regression equation for the four variables.

$$
\begin{gathered}
Y_{1}=0,0940 X+e_{1} \\
Y_{2}=0,5665 X-0,0421 Y_{1}+e_{2} \\
Y_{3}=0,1201 Y_{1}+0,4585 Y_{2}+e_{3}
\end{gathered}
$$

Each equation describes the contribution of every independent variable on the dependent variable. Then the symbols e1, e2, and e3 is a residual variable. Variable residuals are other variables that affect the dependent variable but not examined in the research. Although every variable regression coefficient is already known, but the results do not yet describe the contributions of every variable clearly. Therefore, any regression coefficients must be converted into the form percent.

The formula used to finds the influence of the independent variables in percent is the value of beta quadrate. Then to determine the effect of residual value in the form percent are reducing the value of $100 \%$ with a beta coefficient quadrate. Mathematically, the formula can be written as follows.

$$
\begin{aligned}
w & =\beta^{2} \times 100 \% \\
e & =100 \%-w
\end{aligned}
$$

Note:

$\mathrm{W}=$ Influence of The Independent Variable

e $\quad=$ Influence of The Residual Value

The results of these calculations are presents in tabular form. For more details, can be seen in Table 1. Then the results in the table are presents in the form of path analysis model in 
the percent to be easily understood. This model can be seen in Figure 2.

Based on Figure 2 it can be concluded that all the residual value percentage of contribution are greater than the independent variables were observed. The independent variables with the greatest contribution is the school environment to geo-literacy $(32.09 \%)$ and geo-literacy towards spatial intelligence $(21.02 \%)$. While the independent variables with the smallest contribution is affordance to geo-literacy $(0.17 \%)$, the school environment to affordance $(0.88 \%)$, and the spatial affordance (1.44\%). The conclusion that can be taken from the research is that the influence of the school environment towards spatial intelligence most effective if it involves variable geo-literacy.

TABLE I. THE INFLUENCE OF INDEPENDENT VARIABLE AND RESIDUAL VALUE IN THE FORM OF PERCENT

\begin{tabular}{|c|r|r|r|r|}
\hline Model & $\boldsymbol{\beta}$ & $\boldsymbol{\beta}^{\mathbf{2}}$ & $\begin{array}{r}\text { Influence of the } \\
\text { Independent } \\
\text { Variable }\end{array}$ & $\begin{array}{r}\text { Influence of the } \\
\text { Residual Value }\end{array}$ \\
\hline $1^{\text {st }}$ & 0,0940 & 0,008836 & $0,88 \%$ & $99,116 \%$ \\
\hline $2^{\text {nd }}$ & 0,5665 & 0,320923 & $32,09 \%$ & \multirow{2}{*}{$67,731 \%$} \\
\hline & 0,0421 & 0,001772 & $0,17 \%$ & \multirow{2}{*}{$77,535 \%$} \\
\hline $3^{\text {rd }}$ & 0,1201 & 0,014424 & $1,44 \%$ & $21,02 \%$ \\
\hline & 0,4585 & 0,210222 & \multicolumn{2}{|c}{ Source: Researcher Analysis, 2016} \\
\hline
\end{tabular}

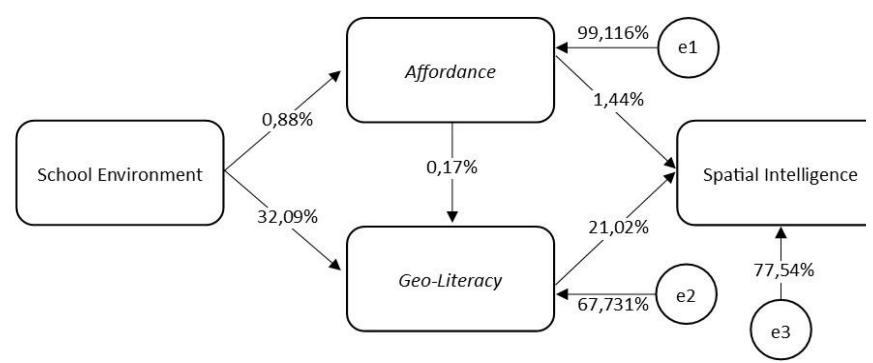

Fig 2. Full Path of diagram research model with residual (Percentage)

School environments affect the affordance is defined as the environment school that is associated with the development of spatial intelligence and increase affordance learners. Researchers suspect that the school environment in accordance with this criterion is a school environment that has a lot of visual objects in the vicinity, either in the form of a floor plan of the school, the class label, paintings, photographs, wall magazines and so on. Affordance theory used in this study to measure the diversity of perceptions on the environment held learners at the high school level. Learners at the high school level are generally aged 17 to 19 years. In this phase the thinking skills they already are high enough to understand something that is complex. Surely it affects the affordance that they have. Besides affordance, the interaction of learners with the school community and other objects that exist in the school environment has an influence on their behavior.

Learners who have a high affordance characterized by their ability to create a variety of actions in certain environment. The word "create" refers to the ability to think and to outline the steps of an actions and not doing any acts alone. For example, learners with high affordance can rearrange the classroom into an exhibition space that is attractive to the needs of the exhibition of works of art. In addition to the exhibition space, learners were able to use objects in the classroom to support the exhibition of the art works. Meanwhile learners with low affordance will only put the paintings or sculptures in the classroom without thinking about how the arrangement pattern so interesting.

Based on the analysis path that has been done, the school environment variable significant influences amounted to 0.553 units (standardized regression) to variable geo-literacy. Whereas the variable affordance not significantly affects the variable geo-literacy. This indicates that in the model equations are second only environment variables schools that can explains and predicts variable geo-literacy. Affordance variable does not affect the geo-literacy variable for variable affordance can be located as a moderating variable.

In this research, spatial intelligence learners measured through three abilities, namely cognitive map, cognitive collage, and spatial mental. Cognitive map is the ability of learners to remember the location of an object, event, or place and placing the other locations are known. Map of mental or cognitive map is a basic ability in spatial intelligence. Mental map is seen as a requirement both for human survival and for the behavior of spatial every day (National Research council, 2006). Learners be able to move from one place to another well for the ability of cognitive this folder. Spatial intelligence also makes it easy for learners to choose the right location to meet their needs. Surely it is supported by the amount of information it holds. For instance, a learner wants to find books to complement the paper, then he will look for the library. In his mind, he will map out the location of the library and compares with its location at the time. Once he knows the location relatives to the library, learners will look for the shortest route to reach the place he wants to go. Even such learners can analyze multiple routes to find the best route to his trip.

The second abilities of spatial intelligence is a cognitive collage. Maps depict not only the world statically, because The use of digital technology and Geoinformatics is adapting to the new forms of organization and presentation of spatial data (R.P Gupta, 2013). This means that the map is not only presents information static, but also dynamic. Map cognitive ability will not work optimally if not accompanied with information that is dynamic. Cognitive collage is a capability that represents the location of the actual and dynamic, so the ability is used to supplement the first ability, the cognitive map. When learners has already mapped the locations he wants to go in his mind, then cognitive collage gives a visual representation of these locations. A visual representation is derived from the experience gained in the past. Spatial thinking skills must be supported by a lot of information obtained from the exploration of the surrounding environment. Any information received will help learners to analyze spatial phenomena. Learners who have exploration experiences that many will 
have the cognitive ability collage higher than learners who experiences low exploration.

The third ability of spatial intelligence is the spatial mental. Spatial mental is the highest ability in spatial intelligence. Spatial mental indicated by the mind's ability to represent processes that occur in the environment in mind. The function of this ability is to explain the causes of a phenomenon and predicts the effects of a phenomenon. The higher a person's ability spatial mental aspects of this, the higher the person's ability in predicting the phenomena in space. The variable of affordance and geo-literacy variables have different contributions in influencing spatial intelligence. More precisely geo-literacy variable has a greater contribution than affordance variables in determining the level of spatial intelligence learners. Geo-literacy is a concept that involves spatial intelligence into business decision-making is comprehensive. Affordance is the perception of the environment that determines one's actions in a spatial context. All three of these variables have in common is to explain concepts related to spatial context. Later the relationship is strengthened by the results of the path analysis showed these two variables are positive effect on spatial intelligence. In addition, the use of computers in Geography can be another factor influencing spatial intelligence. Computers have become an increasingly important and popular platform for the administration of practice tests within institutions of higher education (Sutomo, 2013).

The results of this research indicates that the arrangement of the school environment can be planned to develop spatial learners through increased affordance and geo-literacy. Any object such as posters, bulletin boards, school floor plans to the directions has its own role in enhancing these variables. The school environment is an important stimulus to direct the behavior of spatial learners become more effective and efficient. To improve affordance, the school environment should be designed with a variety of locations information such as a complete floor plans, directions, until signs of school. It is intended that the learners are accustomed to thinking using pictures. Image has a great influence in the improvement of affordance because the image has the ability to convey a lot of meaning compared with information in the form of writing. Images can open a new perceptions of the environment.

Geo-literacy as a second variables that is influenced by the environments has a greater influence on the spatial intelligence than the affordance. Follow-up to do in this regards is to use the environment as a means to address issues concerning the environment and terrestrial. The move is predicted to increase spatial learners, because these issues will stimulate learners to think laterally (branching). If affordance supports spatial aspects of perception, then geo-literacy supports spatial aspects of geographic knowledge. Geographic knowledge can be transferred out of the school environment for learners through the use of appropriate media. If you want to get optimal results, the media used must of course be audio-visual media such as LCD TV with good quality speakers. But if the school environment has limitations to provide this, the media used may be the print media or media models. It should be the main focus not the sophistication of the media, but the completeness of the information conveyed by the media. Even if the media being used only print media, but if the information it conveys a complete and easy to understand learners, slowly the media will affect the mindset of learners. If affordance supports spatial intelligence aspects of perception, then geo-literacy supports spatial intelligence aspects of geographic knowledge.

Geographic knowledge can be transferred from the school environment for learners through the use of appropriate media. If you want to get optimal results, the media used must of course be audio-visual media such as LCD TV with good quality speakers. But if the school environment has limitations to provide this, the media used may be the print media or media models. It should be the main focus not the sophistication of the media, but the completeness of the information conveyed by the media. Even if the media being used only print media, but if the information it conveys a complete and easy to understand learners, slowly the media will affect the mindset of learners. School environment as a stimulus affecting the perceptions and spatial knowledge has been proven statistically impacts on spatial intelligence.

The ideal spatial behavior from the standpoint of learning Geography is a behavior that is based on careful consideration of various spatial information owned. Of course, this is a complex thing, but it does not mean that cannot be developed. The progress of time requires people to think more complex and thorough. The mindset of a linear (one-way) will not be able to overcome the problems that occur in modern times. While mindset lateral (forked) will support solving contemporary problems. Mindset lateral one of which can be done through spatial mindset based on the spatial intelligence. This can be exemplified by a tourist from Indonesia to be traveled to Japan in December. The traveler will think about the ongoing season in Japan. Then he will determine what items he will bring to the tour. In December, Japan is experiencing winter, the tourists will bring warm clothes and other items that are able to anticipate the cold. There are many examples of the application of spatial behavior that are useful in everyday life in modern society. Therefore, the concept of spatial intelligence in learning geography should be developed in order to give birth to the concepts of a valid and raw. This meant that every teacher of Geography in Indonesia have the same perception to develop spatial learners at their respective schools.

\section{CONCLUSIONS AND SUGGESTIONS}

Based on the description of the introduction to the discussion, it can be concluded three main things being the result the research. The conclusions are as follows.

- The school environment affects the affordance of $0.88 \%$. But the school environment does not significantly affect the affordance learners.

- The school environment is significantly positive effects to geo-literacy and affordance not significantly 
influence the geo-literacy. As for the influence of the school environment towards geo-literacy is $32.09 \%$.

- Geo-literacy and affordance significantly positive effects on spatial intelligence. Geo-literacy influence towards spatial intelligence is $21.02 \%$ and the influences towards spatial intelligence affordance is $1.44 \%$.

After observe to this article from introductions until conclusions, the authors propose several recommendations related to the follow-up of the research results. The recommendations made are as follows.

- The emphasis of the concept of spatial intelligence in this research is the cognitive map, cognitive collage and spatial mental. Therefore, the researchers recommended the research results can be used as a references for further research. It is intended that the concepts spatial intelligence for learning geography can be excavated precisely.

- Efforts to improve spatial intelligence can be done through increasing geo-literacy learners. It can be done in various ways, for example, describes an example of actual environmental issues and analyze them from the viewpoint of Geography.

\section{REFERENCES}

[1] A. Klonari, dan A. Likouri, 2015, "The Relation of Multiple Intelligences and Spatial Perception with Performance in Geography Education", Journal for Geographic Information and Science, Published online June 2015, ISSN 2308-1708, DOI: 10.1553/giscience2015, (C) 2011 Elsevier Ltd. Available on http://hw.oeaw.ac.at/?arp=0x00324a5d.

[2] E. Purwanto, (2001), "Pendekatan Pemahaman Citra Lingkungan Perkotaan Melalui Kemampuan Peta Mental Pengamat", Jurnal Dimensi Vol. 29, No. 1, July 2001: 85 - 92, ISSN 2338-7858, available http://dimensi.petra.ac.id/index.php/ars/article/view/15748.

[3] Hespanha, Stacy Rebich, Goodchild, Fiona dan Janelle, G. Donald (2009), "Spatial Thinking and Technologies in the Undergraduate Social Science Classroom", Journal of Geography in Higher Education, Vol. 33, Supplement 1, S17-S27, 2009, ISSN 0309-8265 available on http://www.tandfonline.com/doi/pdf/10.1080/03098260903033998.

[4] I. Oktaviana, (2015), "Pengaruh Lingkungan Sekolah terhadap Motivasi Belajar Siswa Kelas V Sekolah Dasar di Daerah Binaan I Kecamatan Limpung Kabupaten Batang", Thesis in Department of Elementary School Teacher Education, Universitas Negeri Semarang: Semarang, Available on http://lib.unnes.ac.id/21074/1/1401411503-s.pdf.

[5] I. Sudikno, dan Y. Aminah, (2014), "Pengaruh Lingkungan Keluarga, Lingkungan Sekolah, Disiplin Belajar dan Motivasi Belajar terhadap Prestasi Belajar Ekonomi Siswa SMA Kelas XI IPS SMA PGRI 1 Taman Pemalang", Economic Education Analysis Journal Vol 3 No.1 Year 2014, ISSN 2252-6544 available online http://journal.unnes.ac.id/artikel_sju/eeaj/4131.

[6] J. Lee, dan R. Bednarz, (2012), "Components of Spatial Thinking: Evidence from a Spatial Thinking Ability Test. Journal of Geography," $111: 1,15-26$, DOI: 10.1080/00221341.2011.583262, available on http://www.sciencedirect.com/science/article/pii/S1877042811013711.

[7] K. Quinnel, 2015, "Student Perception of Informal Learning Spaces Using Gibson's Theory of Affordances", A Dissertation Submitted to the Faculty in the Educational Leadership Program of Tift College of Education at Mercer University, Published by ProQuest LLC (2015), ProQuest Number: 3664537, Available on http://eresources.perpusnas.go.id/library.php?id=00001.

[8] K. Wilson, C. Boyd, L. Chen \& S. Jamal, (2011), "Improving Student Performance in A First-Year Geography Course: Examining The Importance of Computer-Assisted Formative Assessment", Journal of Computers and Education 57 (2011) page 1493-1500. ISSN 0360-1315. DOI: 10.1016/j.compedu.2011.02.011. (C) 2011 Elsevier Ltd. Available on http://www.sciencedirect.com/science/article/pii/S0360131511000 492.

[9] National Geographic Society, (2009), "Geography For Life, 2nd Edition - National Geography Standards", Geography Education National Implementation Project, Available on http://www.tandfonline.com/doi/pdf/10.1080/19338341.2012.679889.

[10] N. Newcombe, J. Huttenlocher, A.B. Drummey, J.G. Wiley, (1998), "The Development of Spatial Location Coding: Place Learning and Dead Reckoning in The Second and Third Years", Cognitive Development, 13, page 185-200, ISSN 0885-2014 available on http://doi.apa.org/journals/amp/51/2/77.pdf.

[11] National Research Council, (2006). "Learning to think spatially: GIS as a support system in the K-12 curriculum", The National Academies Press: Washington, Available on http://esrik12gis.emich.edu/k12/PDF/Learning\%20to\%20Think\%20Spa tially.pdf.

[12] R.P. Gupta, (2013), "A Study of the Effect of School Environment on the Academic Achievment of $10^{\text {th }}$ Class Students", Indian Journal of Health and Wellbeing, 2013, 4(8), 1615-1618, ISSN 2321-3698, available on http://files.eric.ed.gov/fulltext/ED542331.pdf.

[13] Sutomo, (2013), "Kompetensi Pembelajaran Geografi dalam Penanaman Konsep Geo-Spasial Siswa Untuk Pembangunan Karakter", Jurnal Geo Edukasi Volume 2 No.1 March 2013. ISSN: 2085-2436 available http://geoedukasi.ump.ac.id/index.php/geoedukasi/article/view/87. 